\title{
Bacterial production and respiration in suspended aggregates - a matter of the incubation method
}

\author{
Helle Ploug ${ }^{1, *}$, Hans-Peter Grossart ${ }^{2}$ \\ ${ }^{1}$ Max Planck Institute for Marine Microbiology, Celsiusstr. 1, 28359 Bremen, Germany \\ ${ }^{2}$ Institute for Chemistry and Biology of the Marine Environment (ICBM), University of Oldenburg, PO Box 2503, \\ 26111 Oldenburg, Germany
}

\begin{abstract}
Bacterial growth rates and carbon production rates were measured by thymidine and leucine incorporation on aggregates formed after incubation, in rolling tanks, of water samples from the River Weser, Germany. Thymidine and leucine incorporation rates per aggregate decreased with increasing pool size when several aggregates were incubated together in a vial under still conditions. The thymidine and leucine incorporation rates per aggregate were on average 5.6- to 5.3-fold lower, respectively, when 5 aggregates were pooled together in vials than those of aggregates which were incubated individually and kept in suspension. The use of oxygen microelectrodes showed that, in contrast to when single aggregates were suspended, the mean diffusion distance for solutes in the surrounding water of the aggregates increased when aggregates were pooled together in vials and incubated under still conditions. Bacterial production and respiration rates were determined by combined radiotracer and microelectrode measurements on 36 individual aggregates, which were suspended during measurements. The average bacterial carbon production and respiration rates were $5.1 \pm 6.3$ and $8.5 \pm 11.6 \mathrm{ng} \mathrm{C} \mathrm{agg}{ }^{-1} \mathrm{~h}^{-1}$, respectively. The average growth rate constant $(\mu)$ was $1.24 \pm 0.32 \mathrm{~d}^{-1}$ and the average growth efficiency was $0.35 \pm 0.19$. Our results demonstrate that the exchange of solutes, e.g. oxygen and radiotracers, between the aggregates and the surrounding water is reduced when aggregates are pooled in a vial as opposed to when they are suspended. Previous measurements may, therefore, have underestimated bacterial growth in aggregates due to the incubation method used.
\end{abstract}

KEY WORDS: Radiotracers · Microelectrodes · Microenvironments · Diffusion · Sinking

\section{INTRODUCTION}

A large portion of suspended matter in oceans, rivers and lakes exists as aggregates composed of phytoplankton, bacteria, flagellates, exopolymers, detritus and inorganic matter (Alldredge \& Silver 1988, Alldredge et al. 1993, Eisma 1993, Grossart \& Simon 1993, Zimmermann \& Kausch 1996). The carbon demand for biomass production of the aggregate-associated bacteria has previously been found to be so low that months to years would be required for bacteria to consume all the organic carbon of aggregates sinking out of the

\footnotetext{
- Present address: Marine Biological Laboratory, University of Copenhagen, Strandpromenaden 5, 3000 Helsingør, Denmark.E-mail: helle_ploug@inet.zitech.dk
}

euphotic zone (Karl et al. 1988, Simon et al. 1990, Smith et al. 1992). Hence, other processes such as enzymatic hydrolysis and respiration are considered to be the major microbial processes in aggregate decomposition (Smith et al. 1992, Grossart \& Simon 1998, Parparov et al. 1998, Ploug et al. 1999). The turnover time of carbon on marine aggregates due to respiration in darkness has recently been shown to be 1 to $2 \mathrm{wk}$ (Ploug et al. 1999). The high enzymatic hydrolysis rates and respiration rates, but apparently low bacterial production rates, suggest a very low growth yield of attached bacteria, and the question as to why the bacteria appear not to utilize the aggregate carbon and nutrients more efficiently remains open.

Steep gradients in oxygen concentration and $\mathrm{pH}$ in marine snow, and even anoxic conditions in large fecal 
pellets, have been demonstrated with microelectrodes (Alldredge \& Cohen 1987). It has been hypothesized that diffusion limitation and the chemical microenvironment, e.g. anoxia and low $\mathrm{pH}$, of sinking aggregates may limit growth of the attached bacterial community (Azam et al. 1993). The development of a vertical flow system in which aggregates are stabilized in suspension by an upward flow velocity that opposes the sinking velocity of the aggregates has enabled direct measurements of mass transfer and the oxygen microenvironment in aggregates during sinking (Ploug \& Jørgensen 1999). Oxygen concentrations in natural marine snow were seldomly lower than $90 \%$ of air saturation during sinking, although the turnover time of the aggregate carbon by respiration was short (Ploug et al. 1999). Sinking of aggregates greatly facilitates diffusion of oxygen from the surrounding water to the aggregates, resulting in a 9-fold higher oxygen concentration inside aggregates compared to that in an aggregate sedimented onto a solid surface. The flow past the sinking aggregates is, therefore, important for its oxygen microenvironment and the exchange of solutes between the aggregate and the surrounding water (Ploug \& Jørgensen 1999).

Aggregate-associated bacterial production rates have traditionally been measured by pooling several aggregates in a common sample of a few $\mathrm{ml}$ of surrounding water in order to limit the variability among individual aggregates, and, thus, to obtain more representative measurements (Simon et al. 1990, Smith et al. 1992, Grossart \& Simon 1993, 1998). Here we examine the effect of the pooling of aggregates on the diffusive exchange of oxygen in the samples during incubation, and its effect on measured bacterial production rates as compared to more natural conditions where the aggregates were maintained suspended. The combination of radiotracer and microsensor techniques allowed us to measure bacterial production rates and respiration rates on the same aggregate and so directly determine the growth efficiency of aggregate-attached bacteria.

\section{MATERIALS AND METHODS}

Sampling and aggregate formation. In July 1998 water samples were collected in a Van Dorn bottle from the surface of the River Weser at the station 'Etelsen', ca $20 \mathrm{~km}$ south-east of Bremen, Germany. The salinity was $<1.0 \%$. Samples were incubated in $1.4 \mathrm{l}$ plexiglass roller tanks at $2.5 \mathrm{rpm}$ at in situ temperature $\left(22^{\circ} \mathrm{C}\right)$ in the dark for aggregate formation (Shanks \& Edmondson 1989). Aggregates $\geq 0.7 \mathrm{~mm}$ in diameter were already formed after $2 \mathrm{~h}$ of incubation and were used for production and respiration measurements of the aggregate-associated microbes.
Bacterial production rates. The microcentrifugation method was used (Smith \& Azam 1992). Incorporation of $\left.{ }^{3} \mathrm{H}\right]$-thymidine (TdR; Fuhrman \& Azam 1980) and $\left[{ }^{14} \mathrm{C}\right.$-leucine (Leu; Kirchman et al. 1985, Simon \& Azam 1989) into ice-cold trichloroacetic acid precipitate was measured using the dual label approach (Chin-Leo \& Kirchman 1988). Triplicate samples and a formalin-killed control were spiked with $\mathrm{TdR}(75 \mathrm{Ci}$ $\mathrm{mmol}^{-1}$ ) and Leu $\left(312 \mathrm{mCi} \mathrm{mmol}^{-1}\right.$ ) (both from Amersham), and incubated at in situ temperature for $1 \mathrm{~h}$ in the dark. Aggregates of comparable size were incubated in $5 \mathrm{ml}$ of sterile filtered water in 3 different ways: aggregates were pooled in 1 vial, in which they were either (1) separated, or (2) clustered together at the bottom under still conditions; alternatively, (3) single aggregates were kept in suspension by rotating the incubation vial vertically at $2.5 \mathrm{rpm}$ on a roller table. Final concentrations of the radiotracers ranged from 10 to $360 \mathrm{nM}$ and were used to determine uptake kinetics for both tracers. Bacterial cell multiplication was calculated from ${ }^{3} \mathrm{H}-\mathrm{TdR}$ incubation assuming an isotope dilution factor of 4 (Simon 1990) and a theoretical conversion factor of $0.5 \times 10^{18}$ cells $\mathrm{mol}^{-1} \mathrm{TdR}$. Carbon biomass production by attached bacteria was calculated from ${ }^{14} \mathrm{C}$-Leu incorporation, assuming an intracellular isotope dilution factor of 2 and a carbon:protein ratio of 0.86 of the bacterial biomass (Simon \& Azam 1989). Bacterial production was calculated as in Grossart \& Simon (1998), assuming 53 fg protein cell ${ }^{-1}$ on aggregates.

Bacterial enumeration. Bacteria on aggregates were counted after DAPI staining by epifluorescence microscopy (Porter \& Feig 1980). To remove attached bacteria, single aggregates were treated by ultrasound in 2 mM Na-pyrophosphate (Velji \& Albright 1986) prior to filtration onto $0.2 \mu \mathrm{m}$ Nuclepore membranes.

Microelectrode measurements. Oxygen gradients were directly measured at steady state in pooled samples of aggregates in vials similar to those used for bacterial production measurements, and in individual sinking aggregates which were kept in suspension by an upward-directed flow opposing their sinking velocities (Ploug \& Jørgensen 1999). Ten liters of surface water were filtered through microfibre glass filters $(\mathrm{GF} / \mathrm{C})$ and filled into the flow system. All measurements were done at in situ temperature $\left(22^{\circ} \mathrm{C}\right)$, using a slender Clark-type microelectrode (Revsbech 1989) with a $4 \mu \mathrm{m}$ wide sensing tip, a $90 \%$ response time of $0.5 \mathrm{~s}$, and a stirring sensitivity of $<0.3 \%$. The microelectrode was calibrated in air-saturated and in $\mathrm{N}_{2}$ flushed water. The electrode signal was measured by a picoammeter connected to a strip chart recorder. The position of the aggregate surface was determined by slowly advancing the microelectrode towards the aggregate until it visibly touched the upper surface, as 
observed under a dissecting microscope. The oxygen gradients were measured in the diffusive boundary layer (DBL) at $50 \mu \mathrm{m}$ step intervals at steady state in darkness. The dimensions of the aggregates were measured under the dissecting microscope while they were in the flow system. The same aggregates were used for bacterial production measurements immediately after the microelectrode measurements.

Analysis of oxygen gradients. The measured oxygen gradients in the DBL during sinking were used to determine the oxygen fluxes and thereby the respiration rates in the aggregates (Ploug et al. 1997). A respiratory quotient of $1.2 \mathrm{~mol} \mathrm{O}_{2}: 1 \mathrm{~mol} \mathrm{CO} 2$ was assumed. The diffusion coefficient for oxygen in water at salinities $<1 \%$ and at $22^{\circ} \mathrm{C}$ is $2.24 \times 10^{-5} \mathrm{~cm}^{2} \mathrm{~s}^{-1}$ (Broecker \& Peng 1974). The diffusion calculations were made for an ellipsoid as described in Ploug et al. (1999).

\section{RESULTS}

The aggregates contained very few phytoplankton cells, but also high amounts of detritus and some resuspended mineral grains. Bacterial numbers per aggregate ranged from $1.0 \times 10^{6}$ to $1.5 \times 10^{6}$. The average diameter of single aggregates was $1.14 \pm 0.36 \mathrm{~mm}$, and their average volume was $4 / 3 \pi \times(0.57 \mathrm{~mm})^{3}=0.79 \mathrm{~mm}^{3}$ The longest axis was always less than 2 times larger than the shortest axis. TdR and Leu incorporation rates per aggregate were measured in samples of different numbers with densely clustered aggregates and with aggregates which were well-separated within the vials (Fig. 1). The bacterial production rates were systematically higher on aggregates which were well-separated than on clustered aggregates. Incorporation rates of both TdR and Leu tracers per aggregate were highest when only 2 aggregates were pooled in a vial, and decreased with increasing number of aggregates within a vial. Oxygen concentrations within the samples also decreased with increasing number of aggregates per vial (Fig. 2). Oxygen concentration was saturated in the upper few mm of the vials, but a gradient of oxygen developed towards the bottom of the $5 \mathrm{~cm}$ long vial on which the aggregates were sedimented (data not shown). The steepest oxygen gradients occurred at the interface of the aggregates and the surrounding water at distances $\leq 1.5 \mathrm{~mm}$ above the surface of the sample. Mass transfer of oxygen into the aggregates occurred mainly by molecular diffusion in this boundary layer, since diffusion of oxygen from below was prohibited by the solid surface of the vial. Anoxia was only detected when 40 of these relatively small aggregates were pooled together in a volume of ca $31 \mathrm{~mm}^{3}$, leading to increased diffusion distances within the $2 \mathrm{~mm}$ deep sample with concurrent oxygen
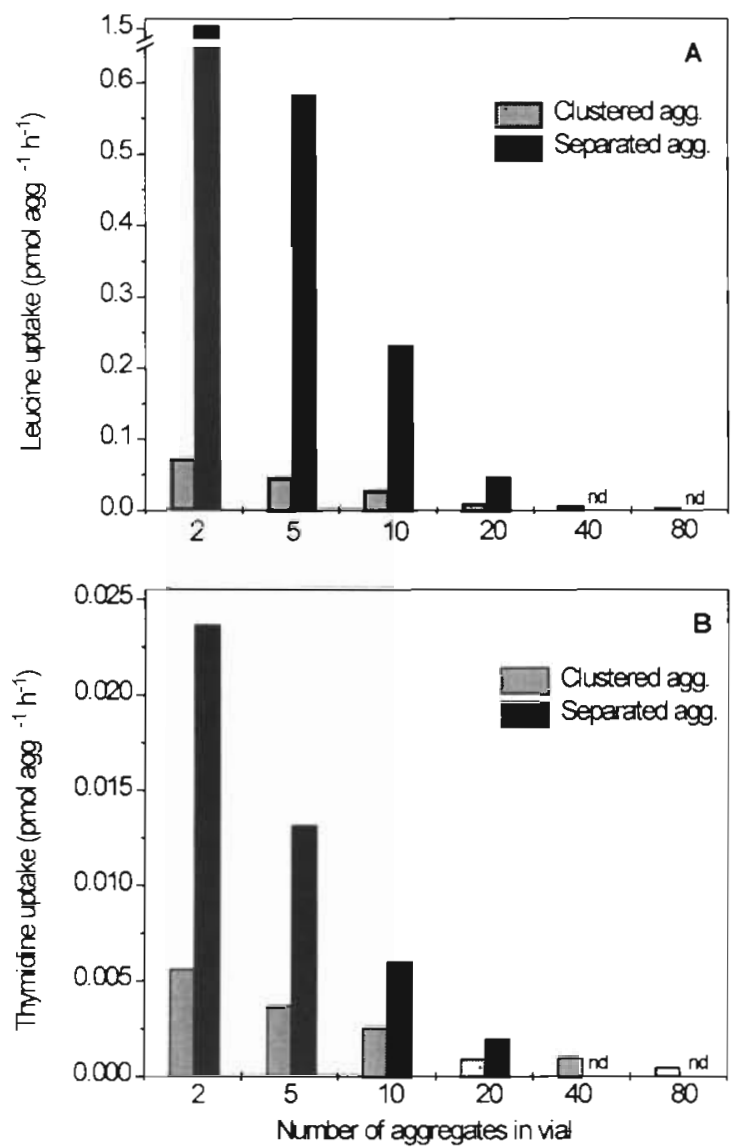

Fig. 1. (A) Leucine and (B) thymidine incorporation rates per aggregate measured with different pool sizes of the samples when the aggregates were separated and clustered in the vials. Bars: mean value of 3 series of measurements for pool sizes up to 20 agg sample ${ }^{-1}$. nd: not determined for separated aggregates

uptake. In contrast, single aggregates were always $\geq 85 \%$ saturated with oxygen due to a much smaller diffusion distance from the surrounding water into single aggregates, which had a high exposed surface area to volume ratio. The respiration rates in sedimented aggregate samples could not be calculated from the oxygen gradients because the exposed surface area was difficult to quantify.

Incorporation kinetics for $\mathrm{TdR}$ and Leu were studied in detail with pools of 5 aggregates densely clustered and with 5 aggregates separated within the vials (Fig. 3). We used triplicate samples of aggregates for each measuring point, i.e. 130 to 175 aggregates for each series of measurements. The measured data were fitted to Monod kinetics by a non-linear regression Levenberg-Marquardt algorithm (Origon 3.0, MicroCal Software, Inc.). Maximum incorporation rate, $V_{\max }$ increased 1.9- and 2.3-fold for Leu and TdR, respectively, when aggregates were separated within the sample, compared to clustered aggregates. The maximum in- 


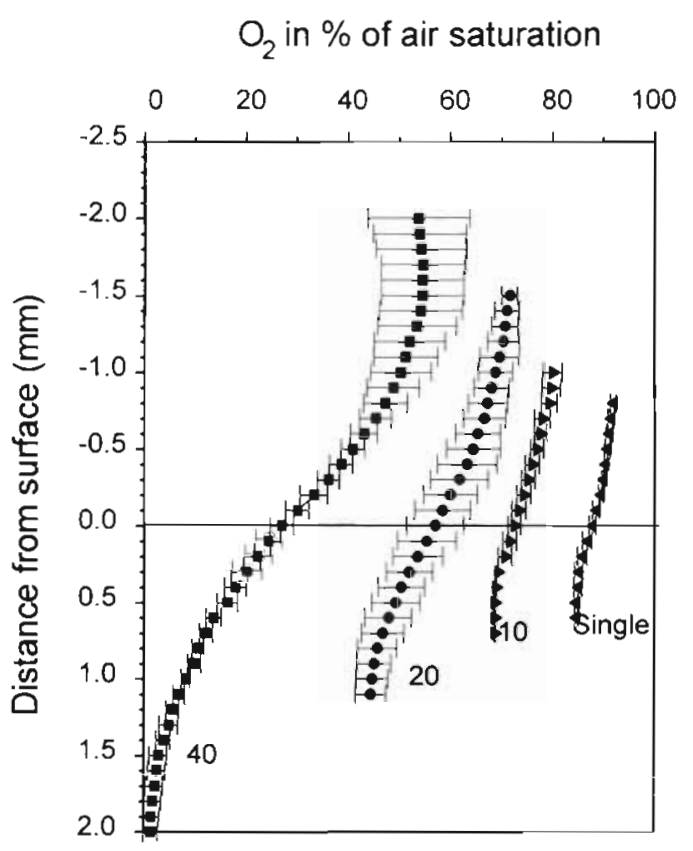

Fig. 2. Oxygen distributions in samples of different pool sizes. Numbers on the curves: numbers of aggregates being clustered together in the sample. Each profile represents the mean value of 3 series of measurements with the SD of the mean corporation rate for $\mathrm{TdR}$ was 46 -fold lower than that of Leu when aggregates were separated within the samples. The apparent half saturation constant, $K_{\mathrm{M}}$, did not change significantly under different incubation conditions. $K_{M}$ was $25 \mathrm{nM}$ for Leu and 14 to $16 \mathrm{nM}$ for TdR. Uptake rates thus increased at all substrate concentrations when the aggregates were separated, compared to when they were clustered within the vials.

Maximum incorporation rates for $T d R$ in clustered and separated aggregates (Fig. 3) were nearly similar to the incorporation rates shown in Fig. 1 when 5 aggregates were pooled. The measured uptake rates of Leu were more variable. Maximum incorporation rate for Leu in the 5 separated aggregates shown in Fig. 3 was similar to the incorporation rate shown in Fig. 1. In clustered aggregates, however, $V_{\max }$ was 6 -fold higher in Fig. 3 compared to the uptake rate shown in Fig. 1. Uptake rates at saturating tracer concentrations were almost constant, with small standard deviations in samples where the aggregates were clustered together. In contrast, the uptake rates were relatively more scattered in samples when the aggregates were separated (Fig. 3). These differences may have been caused by differences between individual aggregates. Variable
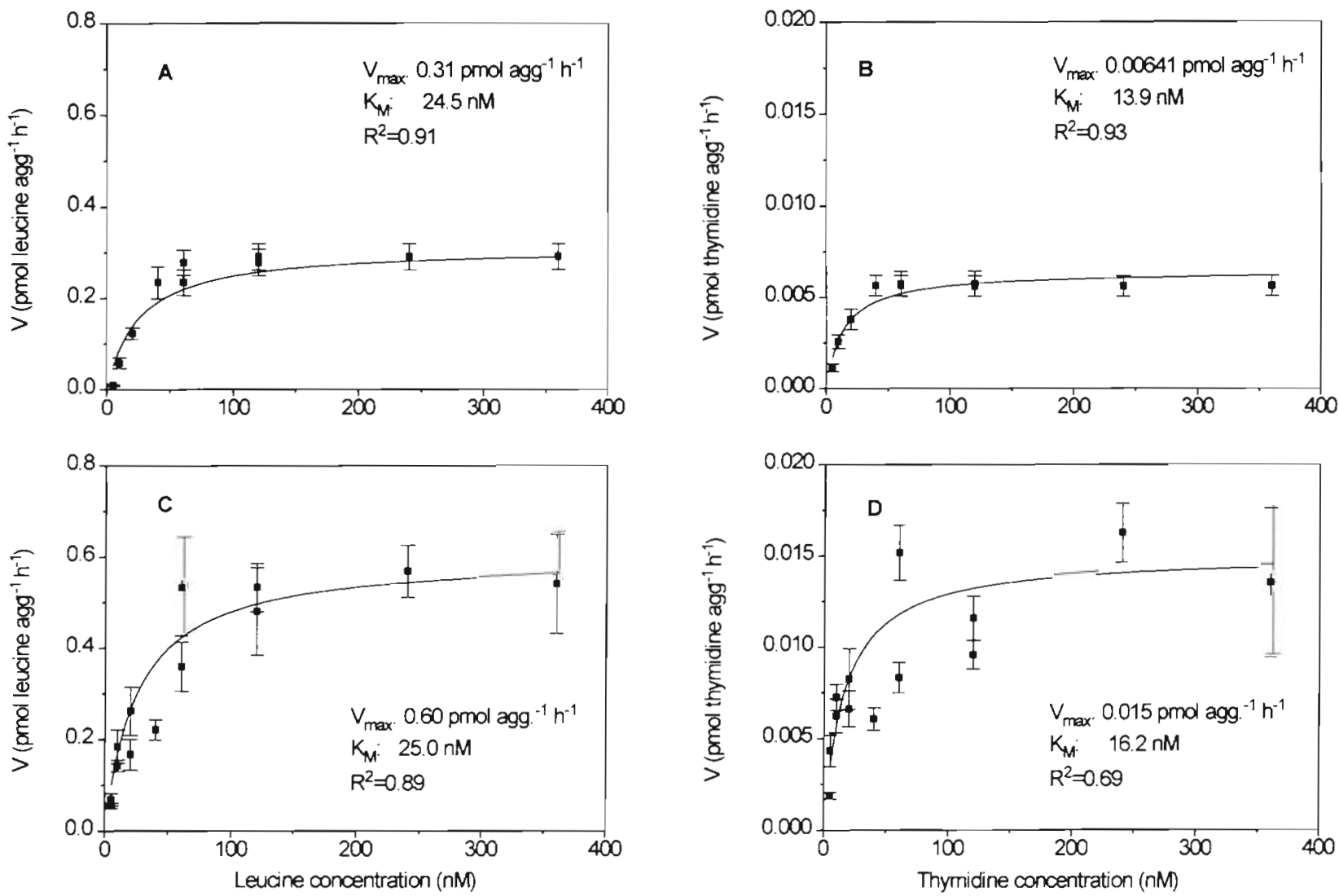

Fig. 3. Leucine and thymidine incorporation rates per aggregate measured with 5 aggregates in each sample, when the aggregates were $(A, B)$ clustered and (C, D) separated in the vials. Each data point represents the mean value with the $S D$ of the mean ( $n=3$ ) 
distances between aggregates could also create different microenvironments in terms of substrate concentrations and hence alter the general growth conditions in the bacterial community.

In a second series of experiments, single aggregates were incubated separately and maintained in suspension during measurements of bacterial production and respiration, to allow the measurements to be done under more natural conditions. Sinking velocities of the aggregates were $>100 \mathrm{~m} \mathrm{~d}^{-1}$ or $1.15 \mathrm{~mm} \mathrm{~s}^{-1}$. Oxygen gradients were measured in the aggregates prior to the bacterial production measurements. An example of the oxygen distribution around and within a sinking aggregate is shown in Fig. 4 . The shortest axis of the aggregates was $0.6 \mathrm{~mm}$ and the longest axis was $1.1 \mathrm{~mm}$. Oxygen concentration was $>97 \%$ of that of the surrounding water in the central part of the aggregate because the flow past the aggregates during sinking enhances mass transfer of oxygen from the surrounding water to the entire surface of aggregates. Oxygen gradients were steepest at the aggregate-water interface. This indicates that respiration mainly occurred close to the aggregate surface. The DBL thickness was $0.125 \mathrm{~mm}$ upstream and $0.310 \mathrm{~mm}$ downstream. The diffusion distance from the surrounding water to the aggregates was thus greatly reduced during sinking as compared to sedimented aggregates (Fig. 2).

The TdR incorporation rate for 36 aggregates ranged from 0 to $0.20 \mathrm{pmol} \mathrm{agg}^{-1} \mathrm{~h}^{-1}$, with a mean value of $0.036 \pm 0.052 \mathrm{pmol} \mathrm{agg}^{-1} \mathrm{~h}^{-1}$ (Table 1$)$. The Leu incorporation rate ranged from 0.06 to $7.77 \mathrm{pmol} \mathrm{agg}^{-1} \mathrm{~h}^{-1}$,
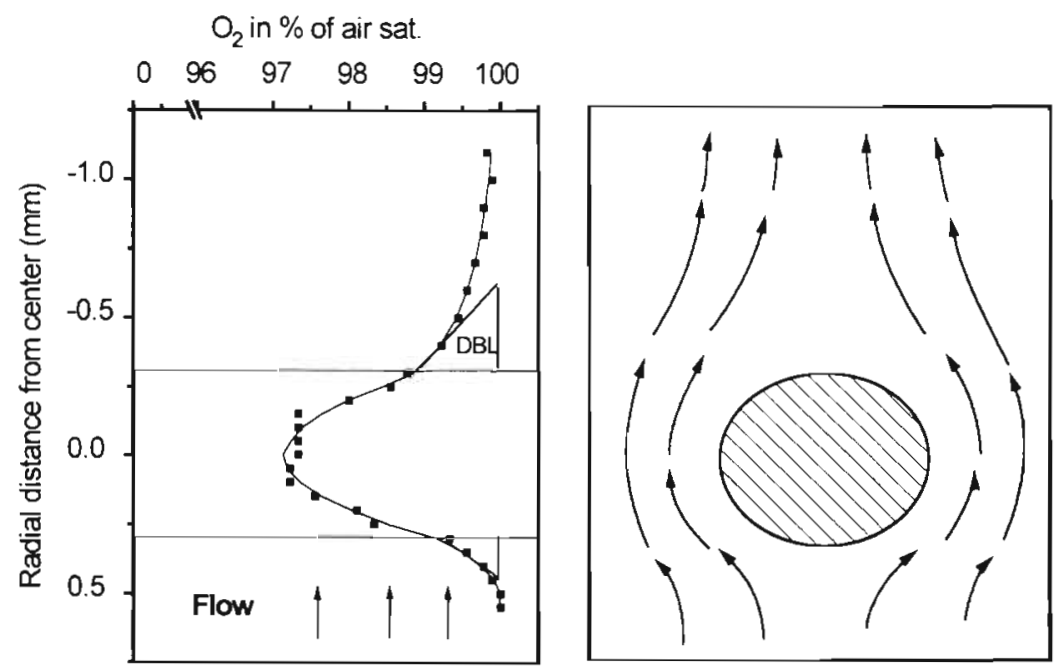

Fig. 4. Oxygen concentrations measured around and within sinking aggregates during darkness. Aggregate was suspended by an upward flow velocity of $140 \mathrm{~m} \mathrm{~d}^{-1}$, which opposed its sinking velocity with a mean value of $1.60 \pm 2.02 \mathrm{pmol} \mathrm{agg}^{-1} \mathrm{~h}^{-1}$. Measurements on single aggregates showed a high variability compared to those on pooled aggregates. However, the average incorporation rates of TdR and Leu in suspended aggregates were 5.6- and 5.3-fold higher than those of the 5 clustered aggregates shown in Fig. 3, and up to 20-fold higher than those of the clustered aggregates shown in Fig. 1. The average TdR incorporation rate of sinking aggregates was 2.4 -fold higher, and that of Leu 2.6-fold higher than when 5 aggregates were separated within the vials, as shown in Fig. 3.

The respiration rates, as calculated from the oxygen gradients measured at $50 \mu \mathrm{m}$ step intervals in the DBL, also varied among the 36 aggregates, ranging from 1 to $51 \mathrm{ng} \mathrm{Cagg}{ }^{-1} \mathrm{~h}^{-1}$. The average respiration rate for single aggregates was $8.5 \pm 11.6 \mathrm{ng} \mathrm{C}$ agg ${ }^{-1} \mathrm{~h}^{-1}$. Bacterial growth rates and net bacterial carbon production (BPP) were calculated from the $\mathrm{TdR}$ and Leu incorporation rates, respectively. The bacterial growth rate constant $(\mu)$ was $1.24 \pm 0.32 \mathrm{~d}^{-1}$ and ranged from 0 to $6.5 \mathrm{~d}^{-1}$. BPP ranged from 0.19 to $24 \mathrm{ng} \mathrm{Cagg}^{-1} \mathrm{~h}^{-1}$, with a mean value of $5.1 \pm 6.3 \mathrm{ng} \mathrm{C} \mathrm{agg}^{-1} \mathrm{~h}^{-1}$. Since bacterial production rates in single aggregates were measured immediately after the respiration measurements on the same aggregates, we were able to directly determine the growth efficiency of the bacterial community, assuming that dark respiration was exclusively due to bacteria. The growth efficiency determined as $\mathrm{BPP} /(\mathrm{BPP}+$ dark respiration) varied from 0.04 to 0.69 in single aggregates, with a mean value of $0.35 \pm 0.19$.

\section{DISCUSSION}

Bacterial production rates in marine and lake snow measured in previous studies show high variability (Table 2 ). Compared to most of the earlier studies, sizes of aggregates in the present study were relatively small, whereas bacterial numbers were similar to those of previous measure- 


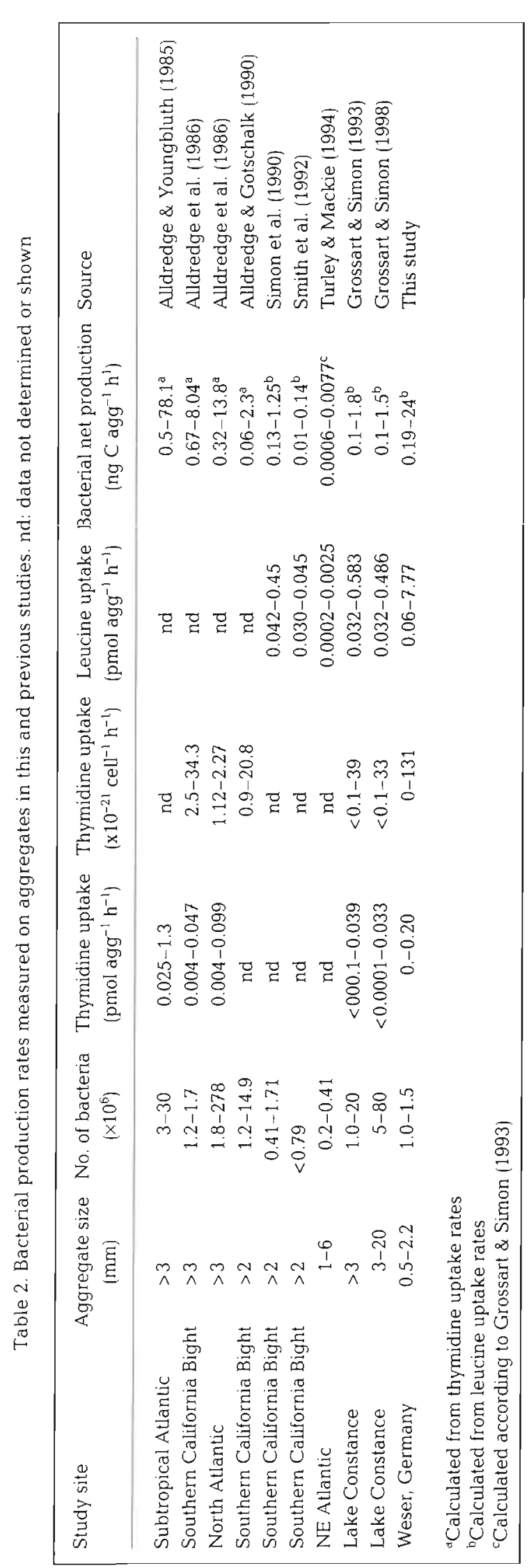

ments on larger marine and limnetic aggregates. The $\mathrm{BPP}$ and the respiration on aggregates similar to those of the present study have been shown to increase with increasing particle size (Grossant \& Plough in press). The bacterial numbers as well as the respiration rates on the aggregates of the present study were similar to those measured for similar sizes of marine snow (Ploug et al. 1999). The incorporation rates of $\mathrm{TdR}$ and Leu measured in the present study also showed a very large variability, but the average values fell in the upper range of previous measurements in marine and lake aggregates (Table 1). The average doubling time measured in the present study was $0.56 \mathrm{~d}$. The doubling time of bacteria attached to aggregates has previously been shown to range between 0.5 and $10 \mathrm{~d}$. Bacterial production rates on aggregates are highly dependent on the origin of the aggregates, e.g. phytoplankton, larvacean or fecal pellets, and miscellaneous aggregates (Ailidredge \& Gotschaik 1990, Simon et ail. 1990, Grossart \& Simon 1998). Bacterial production rates have been measured by TdR incorporation rates in single, disrupted aggregates (Alldredge \& Gotschalk 1990). Those rates fell in the lower range of bacterial net production per aggregate, but the cell-specific rates were similar to those estimated by $\mathrm{TdR}$ incorporation rates in intact and pooled aggregates of other studies (Table 2). Bacterial production rates estimated by Leu incorporation rates, however, have always been low, and in all of those studies 4 to 10 aggregates were pooled during incubation. In the present study, both the TdR and Leu incorporation rates per aggregate increased when intact aggregates were incubated individually and suspended, compared to when the aggregates were pooled during incubation.

The steady-state oxygen gradients showed that the diffusion distance of solutes from the surrounding water to the aggregates is increased when aggregates are sedimented compared to when they are suspended in a flow. The aggregates were too small and the respiration rates too low to produce anoxia in single aggregates. Anoxic conditions were only detected in a ca $31 \mathrm{~mm}^{3}$ large aggregate sample of $2 \mathrm{~mm}$ depth (Fig. 2). The half-saturation constant, $K_{M}$, for oxygen respiration is on the order of $1 \mu \mathrm{M}$ in heterotrophic microorganisms (Focht \& Verstrate 1977). The observed increase in bacterial production rates due to flow in the present study was, therefore, not due to diffusion limitation by oxygen and, hence, energy limitation of the bacterial activities for the relatively small pool size of 5 aggregates.

The DBL thickness of sinking aggregates has been shown to be an important limiting factor for metabolic rates under diffusion limitation (Ploug et al. 1997). Diffusion limitation of biological processes only occurs when the potential biological uptake rates exceed the 
maximum diffusive supply to the microorganisms. At steady state, the substrates are taken up by the microorganisms as fast as they are continuously supplied from the surrounding water through diffusion and advection. The uptake rates increase linearly with the concentration of the substrate in the bulk water phase under diffusion limitation. Hence, the uptake systems are not saturated as long as the biological processes are diffusion limited by a substrate from the surrounding water. In the present study, the saturation of incorporation rates of both tracers apparently started to occur at tracer concentrations $>60 \mathrm{nM}$. At tracer concentrations of 60 to $360 \mathrm{nM}$ the incorporation rates were independent of the bulk water concentration, which indicates that the bacterial uptake could be saturated by adding Leu and TdR at these concentrations (Fig. 3). The uptake rates, however, increased when aggregates were separated or incubated in a flow, compared to densely clustered aggregates. The concentration levels of substrates in the microenvironment of the aggregates may, therefore, be dependent on the exposed surface area and flow.

Cell-specific growth rates of bacteria on aggregates have been shown to decrease, whereas hydrolytic activities increase, with the age of the aggregates, reflecting the quality and bacterial availability of the particulate organic matter (Smith et al. 1995, Unanue et al. 1997). Ecto-enzymatic hydrolysis, e.g. by aminopeptidase, has been shown to play an important role in the solubilization of marine and limnetic aggregates, with a concurrent efflux of hydrolysates to the surrounding waters (Smith et al. 1992, Grossart \& Simon 1998). Bacterial production as measured by Leu incorporation rates was very low in both studies (Table 2), and it was concluded that bacterial production and hydrolysis were loosely coupled on these aggregates. The measurements of hydrolysis were also done with pooled aggregate samples incubated under still conditions. An efflux of hydrolysate to the surrounding water implies that the concentration of the hydrolysate inside the aggregates is higher than that of the surrounding water, i.e. opposite to the oxygen concentration as shown in the present study and in earlier studies (Alldredge \& Cohen 1987, Ploug \& Jørgensen 1999, Ploug et al. 1999). The concentration levels of the hydrolysis products may be close to saturation levels at the uptake sites, whereby hydrolysis and bacterial production appear to be loosely coupled during incubations of pooled and settled aggregates due to relatively large diffusion distances. The isotope will thus be diluted within the sample if Leu is among the hydrolysis products being produced within the aggregate, leading to lower incorporation rates of the added tracer from the surrounding water if the reduced specific activity is not taken into account.
The impact of flow on mass transfer in porous aggregates has been analyzed theoretically and shown to enhance fluxes of solutes, especially those with low diffusion coefficients (Logan \& Hunt 1987). The diffusion coefficient of Leu is $0.73 \times 10^{-5} \mathrm{~cm}^{2} \mathrm{~s}^{-1}$ at $25^{\circ} \mathrm{C}$ (Longsworth $1952 \mathrm{cf}$. Hayduk \& Laudie 1974), and thus 3 -fold lower than that of oxygen. The diffusion and equilibrium time of any solute between the aggregate and the surrounding water is strongly dependent on the diffusion distance as well as on the dimensions of the diffusion field. In a 1-dimensional diffusion field the mean diffusion time, $t$, of any solute is described by (Berg 1983):

$$
t=\frac{s^{2}}{2 D}
$$

where $s$ is the diffusion distance and $D$ is the diffusion coefficient of the chemical solute.

In a 3-dimensional diffusion field, the mean diffusion time over a similar diffusion distance is 3 times shorter, as described by (Berg 1983):

$$
t=\frac{s^{2}}{6 D}
$$

Most aggregate studies have been carried out for aggregates larger than $3 \mathrm{~mm}$. The diffusion field of the solutes between the aggregates and the surrounding water will be 1-dimensional if a pooled aggregate sample occupies the whole bottom of a vial, with increased diffusion distances if the aggregates sit on top of each other. The mean diffusion and equilibrium time for Leu to exchange between the surrounding water and through a pooled aggregate sample with several $3 \mathrm{~mm}$ large aggregates occupying the lower $6 \mathrm{~mm}$ of the vial would be $6.8 \mathrm{~h}$ ( $\mathrm{s}=0.6 \mathrm{~cm}$, cf. Eq. 1), if the boundary layer was ignored. In contrast, the exchange will be much faster if single aggregates sink through the surrounding water. In a 3-dimensional diffusion field, the mean diffusion time for Leu to or from the center of a $3 \mathrm{~mm}$ large aggregate is only $9 \mathrm{~min}\left(s=r_{0}=0.15 \mathrm{~cm}\right.$, cf. Eq. 2), if the boundary layer is ignored. The minimum equilibrium time in our aggregates would be 11.4 ( $\mathrm{s}=0.1 \mathrm{~cm} ; 1$ to 10 pooled aggregates) to $45 \mathrm{~min}$ ( $\mathrm{s}=0.2 \mathrm{~cm} ; 40$ aggregates) in a 1-dimensional diffusion field, whereas it would be as low as $1.4 \mathrm{~min}$ $\left(s=r_{0}=0.06 \mathrm{~cm}\right)$ for single aggregates in a 3-dimensional diffusion field, if the boundary layer were ignored and an effective diffusion coefficient inside the aggregates similar to that in water were assumed.

The DBL thickness and a lower diffusion coefficient in the aggregates imply longer diffusion and equilibrium times. We did not measure the diffusion coefficient inside aggregates, but the diffusion distance for oxygen was directly shown to be larger for sedimented aggregates than for suspended aggregates. The time to reach steady state for oxygen gradients in a 2 to 
$3 \mathrm{~mm}$ large, sedimented aggregate with a DBL thickness of $1 \mathrm{~mm}$ has been experimentally shown to be ca 20 min (Ploug \& Jørgensen 1999). The diffusion and equilibrium time would accordingly be $60 \mathrm{~min}$ for Leu, as the diffusion coefficient for $\mathrm{O}_{2}$ is 3 times larger than that of Leu. The apparently lower bacterial production rates as measured by ${ }^{14} \mathrm{C}$-Leu in samples with many aggregates may thus partly be an artifact of the isotope dilution due to Leu being produced by ecto-enzymatic hydrolysis inside the aggregates, and the non-equilibrium of the isotopes due to their diffusion time relative to the incubation time of $1 \mathrm{~h}$, even in the relatively small aggregates of the present study.

The growth efficiency of the bacterial community in single suspended aggregates was calculated assuming that dark respiration was exclusively due to bacterid. The aggregates of the present study contained very few phytoplankton, and the aggregates were never net autotrophic communities in light (data not shown). Respiration due to protozoa is difficult to measure separately in microbial communities. At steady state, protozoan grazing equals the growth rate of the bacteria. With an average bacterial doubling time of $0.5 \mathrm{~d}$, the bacterial number is doubled within $12 \mathrm{~h}$. The carbon content of aggregate-associated bacteria is on average $60 \mathrm{fg} \mathrm{C} \mathrm{cell}^{-1}$ (Simon et al. 1990). At steady state, the protozoan respiration would be $(0.5 \times 60 \mathrm{ng} C$ $\left.\mathrm{agg}^{-1}\right) / 12 \mathrm{~h}=2.5 \mathrm{ng} \mathrm{C} \mathrm{agg}^{-1} \mathrm{~h}^{-1}$, assuming an average bacterial carbon content of $60 \mathrm{fg} \mathrm{C}^{\mathrm{C}} \mathrm{cell}^{-1}, 10^{6}$ bacteria $\mathrm{agg}^{-1}$, and a $50 \%$ growth efficiency of the protozoa. The average dark respiration of the aggregates was $8.5 \mathrm{ng} \mathrm{C} \mathrm{agg}^{-1} \mathrm{~h}^{-1}$, and protozoan respiration would thus comprise $30 \%$ of dark respiration at steady state, whereby the bacterial growth efficiencies may be underestimated in the present study.

Estimates of bacterial growth efficiencies for natural free-living pelagic bacteria range from $<0.05$ to 0.60 , as recently reviewed by del Giorgio \& Cole (1998). Our estimates of the growth efficiency in aggregates were in the same range or higher than that determined for natural free-living pelagic bacteria (Table 1). Further study with time-series measurements of aggregates similar to those of the present study has shown that the average growth efficiency can be as high as up to $0.50 \pm 0.13$ during the $3 \mathrm{~d}$ after aggregate formation, and it decreases with decreased substrate availability concurrent with changes in the bacterial community composition on the aggregates (Grossart \& Ploug in press).

The incubation of single aggregates in rotating vials results in increased exchange of solutes between the aggregates and the surrounding water and, thus, decreased equilibrium time for the tracers, which allows for short incubation times. In addition, suspension of aggregates creates more realistic conditions of mass transfer and, thus, chemical microenvironments of all substrates for the aggregate-attached microorganisms as experienced in the field. The high bacterial production rates and high growth yields measured in the present study show that bacterial communities attached to aggregates can indeed be highly active, and that bacterial hydrolysis and hydrolysate uptake may be more closely coupled in sinking aggregates than previous studies on sedimented and pooled aggregates have suggested. Whereas bacterial carbon production will transform the aggregate carbon into bacterial biomass, respiration results in a loss of the aggregate carbon as $\mathrm{CO}_{2}$ to the surrounding water when the aggregates are net heterotrophic communities. Carbon transformation due to growth and respiration by aggregate-associated microbial communities can, therefore, be significantly higher than previously assumed in estimates of carbon fluxes in aquatic environments.

Acknowledgements. The microelectrodes were constructed by Gaby Eickert, Anja Eggers, and Vera Hübner at the Max Planck Institute for Marine Microbiology in Bremen. This study was supported by the Max Planck Society, Germany, and the Carlsberg Foundation, Denmark (J. 970213/20-886 to H.P.). We thank Bo Barker Jørgensen and Meinhard Simon for numerous discussions and many helpful comments.

\section{LITERATURE CITED}

Alldredge AL, Cohen $Y$ (1987) Can microscale chemical patches persist in the sea? microelectrode study of marine snow and fecal pellets. Science 235:689-691

Alldredge AL, Gotschalk CC (1990) The relative contribution of marine snow of different origins to biological processes in coastal waters. Cont Shelf Res 10:41-58

Alldredge AL, Silver M (1988) Characteristics, dynamics and significance of marine snow. Prog Oceanogr 20:41-82

Alldredge AL, Youngbluth MJ (1985) The significance of macroscopic aggregates (marine snow) as sites for heterotrophic bacterial production in the mesopelagic zone of the suptropical Atlantic. Deep-Sea Res 32:1445-1456

Alldredge AL, Cole JJ, Caron DA (1986) Production of heterotrophic bacteria inhabiting macroscopic organic aggregates (marine snow) from surface waters. Limnol Oceanogr 31:68-78

Alldredge AL, Passow U, Logan BE (1993) The abundance and significance of a class of large transparent organic particles in the ocean. Deep-Sea Res 40:1131-1140

Azam F, Smith DC, Steward GF, Hagström $\AA$ (1993) Bacteriaorganic matter coupling and its significance for oceanic carbon cycling. Microb Ecol 28:167-179

Berg HC (1983) Random walks in biology. Princeton University Press, Princeton

Broecker WS, Peng TH (1974) Gas exchange rates between air and sea. Tellus 26:21-35

Chin-Leo G, Kirchman DL (1988) Estimating bacterial production in marine waters from simultaneous incorporation of thymidine and leucine. Appl Environ Microbiol 54: $1934-1939$

del Giorgio PA, Cole JJ (1998) Bacterial growth efficiency in 
natural aquatic systems. Annu Rev Ecol Syst 29:503-541

Eisma D (1993) Suspended matter in the aquatic environment. Springer-Verlag, Berlin

Focht DD, Verstraete W (1997) Biochemical ecology of nitrification and denitrification. Adv Microbiol Ecol 1:135-214

Fuhrmann JA, Azam F (1980) Bacterioplankton secondary production estimates for coastal waters of British Columbia, Antartica, and California. Appl Environ Microbiol 39: $1085-1095$

Grossart HP, Ploug $\mathrm{H}$ (in press) Bacterial production and growth efficiencies directly measured on single pelagic aggregates. Limnol Oceanogr

Grossart HP, Simon M (1993) Limnetic macroscopic organic aggregates (lake snow): occurrence, characteristics, and microbial dynamics in Lake Constance. Limnol Oceanogr $38: 532-546$

Grossart HP, Simon M (1998) Bacterial colonization and microbial decomposition of limnetic organic aggregates (lake snow). Aquat Microb Ecol 15:127-140

Hayduk W, Laudie $H$ (1974) Prediction of diffusion coefficients for nonelectrolytes in dilute aqueous solutions. AICHE (Am Inst Chem Eng) Symp 20:611-615

Karl DM, Knauer GA, Martin JH (1988) Downward flux of particulate organic matter in the ocean: a particle decomposition paradox. Nature 332:438:441

Kirchman DL, K'Nees E, Hodson RE (1985) Leucine incorporation and its potential as a measure of protein synthesis by bacteria in natural aquatic systems. Appl Environ Microbiol 49:599-607

Logan BE, Hunt JR (1987) Advantage to microbes of growth in permeable aggregates in marine systems. Limnol Oceanogr 32:1034-1048

Longsworth LG (1953) Diffusion measurements at $25^{\circ} \mathrm{C}$ of aqueous solutions of amino acids, peptides and sugars J Am Chem Soc 75:5705

Parparov AS, Berman T, Grossart H-P, Simon M (1998) Metabolic activity associated with lacrustine seston. Aquat Microb Ecol 15:77-87

Ploug H, Jergensen BB (1999) A net-jet flow system for mass transfer and microelectrode studies in sinking aggregates. Mar Ecol Prog Ser 176:270-290

Ploug H, Kühl M, Buchholz B, Jørgensen BB (1997) Anoxic aggregates - an ephemeral phenomenon in the ocean. Aquat Microb Ecol 13:285-294

Ploug H, Grossart HP, Azam F, Jørgensen BB (1999) Photosynthesis, respiration, and carbon turnover in sinking marine snow from surface waters of Southern California

Editorial responsibility: Tom Fenchel,

Helsingor, Denmark
Bight: Implications for the carbon cycle in the ocean. Mar Ecol Prog Ser 179:1-11

Porter KG, Feig YS (1980) The use of DAPI for identifying and counting aquatic microflora. Limnol Oceanogr 25:943-948

Revsbech NP (1989) An oxygen microelectrode with a guard cathode. Limnol Oceanogr 34:474-478

Shanks AL, Edmonson EW (1989) Laboratory-made artificial marine snow: a biological model of the real thing. Mar Biol 101:463-470

Simon M (1990) Improved assessment of bacterial production: combined measurements of protein synthesis via leucine and cell multiplication via thymidine incorporation. Arch Hydrobiol Beih 34:151-155

Simon M, Azam F (1989) Protein content and protein synthesis rates of planktonic marine bacteria. Mar Ecol Prog Ser 51:201-213

Simon M, Rosenstock B (1992) Carbon and nitrogen sources of planktonic bacteria in Lake Constance studied by the composition and isotope dilution of intracellular amino acids. Limnol Oceanogr 37:1496-1511

Simon M, Alldredge AL, Azam F (1990) Bacterial dynamics on marine snow. Mar Ecol Prog Ser 65:205-211

Smith DC, Azam F (1992) A simple, economical method for measuring bacterial protein synthesis in seawater using 3H-Leucine. Mar Microb Food Webs 6:107-114

Smith DC, Simon M, Alldredge AL, Azam F (1992) Intense hydrolytic activities on marine aggregates and implications for rapid particle dissolution. Nature 359:139-141

Smith DC, Steward GF, Long RA, Azam F (1995) Bacterial mediation of carbon fluxes during a diatom bloom in a mesocosm. Deep-Sea Res 42:75-97

Turley CM, Mackie PJ (1994) Biogeochemical significance of attached and free-living bacteria and the flux of particles in the NE Atlantic Ocean Mar Ecol Prog Ser 115:191-203

Unanue M, Azúa I, Arrieta JM, Labirua-Iturburu A, Egea L, Iriberri J (1998) Bacterial colonization and ectoenzymatic activity in phytoplankton-derived model particles: cleavage of peptides and uptake of amino acids. Microb Ecol 35:136-146

Velji MJ, Albright LJ (1986) Microscopic enumeration of attached marine bacteria of seawater, marine sediment fecal matter, and kelp blade samples following pyrophosphate and ultrasound treatments. Can J Microbiol 32 $121-126$

Zimmermann $H$, Kausch $H$ (1996) microaggregates in the Elbe Estuary: structure and colonization during spring Arch Hydrobiol Spec Iss Adv Limnol 48:85-92

Submitted: March 17, 1999; Accepted: May 10, 1999

Proofs received from author(s): October 19, 1999 